\title{
Bank Sentral dan Lingkungan Politik Ekonomi: Pengalaman Indonesia
}

\author{
Fachry Ali \\ Direktur Lembaga Studi dan Pengembangan Etika Usaha (LSPEU Indonesia)
}

\begin{abstract}
A central bank should be performing in the political-economy arena that so often is in situation between conflict and harmony. Because of that, it's not surprising that we often catch a fact that not only the monetary policies are theoretically drawn with technical calculations in which it would be more frequently evaluated politically, but also the authority of political authoritarianism so often suspect the motivation behind the monetary policy, and hence tend to control it. The experience of central bank in Indonesia under the transition from New Order to Reforms era could become the historical lesson for our state and society.
\end{abstract}

Kata Kunci: Central bank; authorianism; conflict; harmony; monetary

\section{Bank Sentral, antara Politik dan Moneter}

Pertanyaan tentang apakah sebuah bank sentral merupakan produk politik atau sematamata manifestasi dari keharusan kinerja moneter yang ideal terlalu panjang untuk didiskusikan. Fakta keseharian yang terlihat adalah bahwa bank sentral berkinerja di atas pelataran (setting) yang lebih luas dari yang secara teknikal dibayangkan. Keluasan jangkauan kinerja bank sentral yang melampaui batas-batas teknikal moneter dapat kita lihat pada apa yang dinyatakan Sylvia Maxfied: "A new nation acquires a flag, write a national anthem, and constitutes a central bank." 3 Mudah ditafsirkan bah- wa kalimat Maxfied di atas menggambarkan keberadaan dan peranan sebu- ah bank sentral yang berekspansi ke luar pagar kinerja moneter secara teknikal. Akan tetapi pada saat yang bersamaan, untuk mempertahankan kebe- radaannya yang "sejati", sebuah bank sentral haruslah berkinerja dalam sistem moneter yang bisa dipertanggungjawabkan secara teknikal. Mengapa demikian? Karena tindakan-tindakan yang diambil sebuah bank sentral secara langsung mempengaruhi tingkat suku bunga, jumlah kredit dan pasokan uang. "Semua ini," tulis Frederick Mishkin, "have direct impacts not only on financial markets but also on aggregate output and inflation." 2

Di atas pelataran yang luas - yang berpotensi menstrukturkan hubungan silih-berganti antara "konflik" dan "harmoni" aspek-aspek politik dan ekono- mi-moneter — inilah sebuah bank sentral harus berkinerja. Karena itu tidak mengherankan jika acap kita pergoki sebuah kenyataan bahwa bukan saja kebijakan-kebijakan moneter yang secara teoritis diambil dengan kalkulasi teknikal lebih sering dievaluasi secara politik, melainkan juga otoritas-otori- tas politik secara intrinsik mencurigai motif di balik kebijakan moneter itu, dan karenanya cenderung untuk mengontrolnya.

\section{Bank Sentral dan Uang}

Ini semua terjadi karena munculnya abad bank sentral yang mendominasi perekonomian, terutama di sektor finansial. Tetapi, untuk sampai pada kesimpulan itu, kita harus menengok

\footnotetext{
${ }^{1}$ Sylvia Maxfied, Gatekeeper of Growth: The International Political Economy of Central Banking in Developing Countries (Princeton, New Jersey: Princeton University Press, 1997),h. 3.

${ }^{2}$ Frederick S. Mishkin, The Economics of Money, Banking and Financial Markets (Massa- chussetts: AddisonWesley, 1997), Fifth Edition, h. 389.
} 
Konfrontasi: Jurnal Kultur, Ekonomi dan Perubahan Sosial, 3 (2) Juli 2016, 1-8

P-ISSN: 1410-881X (Print)

Fachry Ali, Bank Sentral dan Lingkungan Politik Ekonomi: Pengalaman Indonesia

DOI: -

http://www.konfrontasi.net/index.php/konfrontasi2

sejarah "uang" secara lebih tipikal. Mengapa tipikal? Karena "uang", sebagai alat pertukaran, dalam konteks sejarah, adalah sesuatu yang menembus atau merembes batas-batas "kamar" aktivitas manusia. Sebagaimana di nyatakan sejarawan Perancis terkenal Fernand Braudel, daya rembes alat tukar itu terjadi karena "[m]oney every- where contrives to insert itself into all economic and social relationships." Sifat dan peran yang tak mengenal tapal batas ini telah menyebabkan "uang" bukan saja faktor yang mendinamisasikan aktivitas kehidupan manusia, melainkan juga elusive — sukar dimengerti. Maka tak mengherankan jika Braudel memberikan penilaian yang begitu khusus terhadap sifat dan peran "uang" terhadap manusia:

"Although it is an ancient fact of life, or rather an ancient technique, money has never ceased to surprise humanity. It seems mysterious and disturbing. In the first place, it must have seemed complicated in itself, for the monetary economy that goes with money was nowhere fully developed, even in a country like France in the sixteenth and seventeenth centuries, or indeed in the eighteenth. It only made its way into certain regions and certain sectors, and continued to disturb the others." 3

Untuk memberikan konteks atas daya kejut "uang" di atas, layak kita ikuti penjelasan Braudel lebih lanjut. Yakni bahwa hal yang mengejutkan itu bukanlah terletak pada wujud fisik "uang" itu sendiri, melainkan pada apa pengaruh yang dibawakannya. Apa itu yang dibawakannya? Braudel menjawab: "Keragaman yang tajam dalam harga-harga bahanbahan pokok; hubungan-hubungan tak terperikan di mana manusia tidak lagi mengenal baik dirinya maupun adatnya dan nilai-nilai lamanya. Karyanya menjadi komoditas, dan dirinya sendiri adalah "barang". Menekankan contoh yang lebih kongkret, Braudel menggunakan kata-kata Noël du Fail yang berce- loteh di hadapan para petani tua Breton pada 1548, yang mengungkapkan keheranan dan kebingungan mereka. Jika ada kekurangan di rumah- rumah para petani, itu adalah karena, ujar Noël du Fail:

"[c]hickens and goslings are hardly allowed to come to perfection before they are taken to sell (to the town market of course) for money to be given either to the lawyer or the doctor (people [formerly] almost unknown), to the one in return for dealing harshly with his neighbour, disinheriting him, having him put in prison; to the other for curing him of a fever, ordering him to be bled (which thank God I have never tried) or for a clyster; all of which our late Tiphaine La Bloye of fond memory (a bone setter) cured, without so much mumbling, fumbling and antidotes and almost for a Paternoster." 4

Dan Noël du Fail melanjutkan. "Tetapi sekarang mereka telah memindahkan dari kota ke kampung-kampung kita rempah-rempah dan dan gula-gula yang bermacam-macam, mulai dari lada hingga gula berlapis bawang (sugar-coated leeks) yang sama sekali tidak dikenal nenekmoyang kita. Akan tetapi tanpa itu perjamuan resmi di masa kini menjadi hambar, tidak rapi dan tidak megah. Atas ucapan saya itu, seorang pendengar menyela, 'engkau benar kawan, dan rasa-rasanya saya berada dalam dunia baru." Komentar kebingungan semacam ini, menurut Braudel dapat ditemukan di seluruh Eropa pada masa itu. Sebab, lanjut Braudel: "[a]ny society based on an ancient structure which opens its doors to money sooner or later loses its acquired equilibria and liberates forces that can never afterwards be adequately controlled. The new form

\footnotetext{
${ }^{3}$ Fernand Braudel, The Structure of Everyday Life: The Limits of the Possible, terjemahan dari bahasa Perancis ke dalam bahasa Inggris oleh Siân Reynold (Berkeley, Los Angeles: University of California Press, 1992), h. 436.

${ }^{4}$ Fernand Braudel, The Structure of Everyday Life, h. 436.

${ }^{5}$ Fernand Braudel, The Structure of Everyday Life, h. 437.
} 
Konfrontasi: Jurnal Kultur, Ekonomi dan Perubahan Sosial, 3 (2) Juli 2016, 1-8

P-ISSN: 1410-881X (Print)

Fachry Ali, Bank Sentral dan Lingkungan Politik Ekonomi: Pengalaman Indonesia

DOI: -

http://www.konfrontasi.net/index.php/konfrontasi2

of interchange disturbs the old order, benefits a few previleged individuals and hurts everyone else. Every society has to turn over a new leaf under the impact."8

Semua ini menunjukkan sebuah perubahan dahsyat didalam masyarakat akibat dari penggunaan "uang" sebagai substansi lahirnya hubungan-hu- bungan yang bersifat impersonal dan komersial. Kalimat Braudel tentang masyarakat lama yang kehilangan keseimbangan (loses its equilibria) di atas sejalan dengan deskripsi Heilbroner tentang kemerosotan sistem feodalisme akibat gejala yang sama:

"Feodalism as a legal, political and social organization had to give way to another form of society with a very different set of laws, customs and political institutions."

Tentu, yang dimaksudkan dengan paragraf Heilbroner ini adalah sebuah penggambaran tentang lahirnya masyarakat dengan sistem pasar atau masyarakat kapitalis. Namun, sebagaimana akan kita lihat di bawah, semua itu erat terkait dengan dinamika yang tumbuh karena penggunaan "uang" sebagai alat tukar bersifat impersonal. Pada akhirnya, "uang" telah men- dorong terjadinya revolusi hubungan-hubungan sosial-ekonomi dan politik manusia yang memaksa masyarakat, seperti dinyatakan Braudel di akhir paragraf di atas, membuka lembaran kehidupan baru agar mampu menye- suaikan diri atas pengaruh yang dilahirkannya. Dalam kenyataan sejarah, satu atau dua abad setelah masa deskripsi Braudel itu, sistem keuangan bukan saja telah merevolusikan masyarakat, melainkan merevolusikan dirinya sendiri yang, pada akhirnya, secara tak terelakkan, merevolusikan dunia.

Ini semua berkaitan pada usaha menciptakan dana pendukung bagi Vereenigde Nederlansche Geoctroyeerde Oostindische Compagnie (VOC) pada 1602. VOC ini pada esensinya adalah amalgamasi seluruh perusahaan pelayaran Belanda yang —oleh the Dutch State-General, yaitu parlemen Uni Propinsi (United Provinces) Belanda - dianggap tidak efisien. Lepas dari konteks emosional dalam sejarah Indonesia, kelahiran VOC ini menandai lahirnya inovasi dalam sistem keuangan: joint stock, yaitu sebuah usaha kolektif mendanai sebuah korporasi dengan cara pembelian saham. Yang terjadi, seperti dinyatakan Ferguson, adalah duyunan anggota masyarakat (mulai dari pedagang, artisan, bahkan para budak) berlomba memperoleh saham VOC. Di Amsterdam sendiri, terdapat sebanyak 1.143 pembeli saham atau investor di mana 80 orang di antaranya membeli saham lebih dari 10.000 gulden dan sebanyak 445 orang memiliki saham kurang dari 1000 gulden. Hasilnya adalah 6,45 juta gulden yang membuat VOC "[m] uch the biggest corporation of the era."10

Inovasi finansial ini bukan saja telah menggunakan prinsip limited liability di dalam sistem korporasi, di mana kerugian pemegang saham hanya terbatas pada modal yang diinvestasikan, atau pembayaran dividen (walau untuk pertama kalinya pada 1612, masih dalam bentuk natura, yaitu rempah-rempah), melainkan juga mendorong lahirnya joint-stock company dan pasar modal (stock market) sekaligus, seperti dicatat Ferguson:

"No sooner had the first publicly owned corporation come into existence with the first ever intial public offering of shares, than a secondary market sprang up to allow these share to be bought and sold. It proved to be a remarkably liquid market."

Tingginya tingkat likuiditas ini terjadi karena pada 1607 saja, sepertiga saham VOC telah berpindah tangan dari pemilik semula. Sebagai akibatnya, terutama karena penjualan saham VOC berlangsung dengan tingkat fre- kuensi yang tinggi, jenis perdagangan finansial baru pun muncul: forward market atau futures - pembelian dewasa ini untuk pengantaran barang di kemudian hari. Walau pada mulanya pasar modal ini berlangsung di tempat terbuka, tetapi karena kian lama kian ramai, pada 1608 proses transaksi diselenggarakan di tempat tertutup di Rokin, yang tak terlalu jauh dari Balai Kota. Dengan 
Konfrontasi: Jurnal Kultur, Ekonomi dan Perubahan Sosial, 3 (2) Juli 2016, 1-8

P-ISSN: 1410-881X (Print)

Fachry Ali, Bank Sentral dan Lingkungan Politik Ekonomi: Pengalaman Indonesia

DOI: -

http://www.konfrontasi.net/index.php/konfrontasi2

bentuk ruang bersegi empat (quadrangle), sederet tiang penopang atap (colonnades) dan sebuah menara jam, lahirlah sebuah pasar modal pertama di dunia — meski, kata Ferguson, mirip sekolah Oxford abad pertengahan.

Apa yang penting kita catat di sini adalah bahwa pasar saham pertama di dunia itu memerlukan lembaga keuangan yang menyelenggarakan sirkulasi "uang" secara sistematis ke tempat-tempat yang produktif. Maka, menjadi tak mengherankan jika Amsterdam Exchange Bank lahir pada saat yang sama (1609). Mengapa demikian? Karena, jawab Ferguson, sebuah pasar modal "[c]annot readily function without an effetive monetary system." Maka, sekali bankir Belanda menerima saham-saham VOC sebagai agunan untuk pinjaman, hubungan antara pasar saham dengan aliran pasokan kredit mulai terbentuk. Langkah berikutnya mengalir dengan begitu saja: bank mulai meminjamkan "uang" sehingga sahamsaham bisa dibeli dengan kredit. Dan Ferguson mencatat: "Company, bourse and bank provided the triangular foundation for a new kind of economy."

A new kind of economy (bentuk baru ekonomi) ini, antara lain, adalah sebuah sistem pertukaran barang dan jasa yang bukan saja didasarkan pada sistem pasar, tetapi juga bersifat ekspansif. Di sini aliran modal berimigrasi, melintasi tapal batas negara-bangsa dan benua. Ciri tipikal sistem ekonomi ini adalah bahwa modal tidak lagi berasal dari sumber tunggal, melainkan beragam dan, yang lebih penting — seperti terlihat dalam kasus VOC di atas - tidak berasal dari miliknya sendiri. Dalam ciri yang semacam inilah kita bisa menyebutnya sebagai banking economy, sebuah sistem pereko-nomian di mana arus utama sirkulasi modal lebih berbentuk kredit dan di atur oleh sebuah lembaga yang impersonal, yakni bank. Rumusan ini tampaknya cocok dengan identifikasi "sederhana" Walter Bagehot yang, pada 1870-AN menulis: "The distinctive function of the banker, says Ricardo, 'begin as soon as he uses the money of others." Maka, yang sesungguhnya kita bicarakan di sini adalah ekonomi finansial abad perbankan.

Pada abad-abad ini kita melihat adanya perpaduan antara Belanda dengan Inggris, apa yang disebut Ferguson sebagai Anglo-Dutch merger. Tampak- nya, yang dimaksudkan dengan frase ini adalah migrasi sistem finansial Belanda ke Inggris:

"In particular, the Anglo-Dutch merger of 1688 introduced the British to a number of crucial financial institutions that the Dutch had pioneered. In 1694 the Bank of England was founded to manage the government's borrowings as well as the national currency, similar (though not identical) to the successful of Amsterdam Wisselbank founded eighty-five years before. London was also able to import the Dutch system of a national public debt, funded through a Stock Exchange, where long-term bonds could easily be bought and sold."

Tepat pada saat itu, yaitu pada 1688, Inggris memang sedang mengalami revolusi finansial. Revolusi ini berjalan seiring dengan kemunculan birokrasi Inggris yang dikelola secara lebih profesional, dibandingkan dengan negara- negara Eropa lainnya. Dan salah satu tonggak revolusi finansial tersebut - yang menyebabkan Inggris jauh lebih siap dalam membiayai peperangan - adalah sistem perpajakan yang dibangun secara efektif dan efisien. Gabungan sistem perpajakan yang efektif dan efisien serta revolusi sistem fi- nansial yang menciptakan kemungkinan terjadinya akumulasi modal besar- besaran dan menjadikan Inggris sebagai pusat modal dunia. Dalam konteks inilah, sebuah bank sentral memainkan peran yang crucial.

Sebagaimana dinyatakan Ferguson dalam paragraf yang baru kita lihat di atas, the Bank of England, bank sentral Inggris, didirikan pada 1694 dengan tujuan pengelola keuangan negara baik dalam bentuk pinjaman maupun dari sumber-sumber lainnya. Tetapi hal 
Konfrontasi: Jurnal Kultur, Ekonomi dan Perubahan Sosial, 3 (2) Juli 2016, 1-8

P-ISSN: 1410-881X (Print)

Fachry Ali, Bank Sentral dan Lingkungan Politik Ekonomi: Pengalaman Indonesia

DOI: -

http://www.konfrontasi.net/index.php/konfrontasi2

terpenting di sini adalah pemberian hak istimewa kepada Bank of England pada 1697 sebagai exclusive banking yang mengukuhkan dirinya mempunyai hak exclusive trading - dengan imbalan bahwa bank sentral tersebut sewaktu-waktu harus siap membantu keuangan pemerintah Inggris.16 Maka tak mengherankan kemudian jika the Bank of England bertindak sebagai "pemimpin industri perbankan" Inggris: "raja" dari bank-bank lainnya:

"For, while the general banking business of the country increased rapidly, the bank whether in London or the provinces kept a constantly dimi-nishing proportion to their reserves in cash. They got into habit of keep- ing by them little more than "till money" i.e. enough to meet the ordinary demands of their customers for cash to pay wages, and for other retail transactions. The real reserve was left at the Bank of England."17

Di sini kita melihat muara dari proses kinerja "uang", sebagai alat tukar, yang impersonal dan merevolusikan diri ke dalam sistem finansial inovatif dalam berbagai bentuk jenis dan kelembagaan - adalah pendirian dan perkembangan peranan bank sentral. Tidak mengherankan, jumlah bank sentral bertambah dengan kian berkembangnya perekonomian uang. Data yang diperlihatkan Juliette Healey menyatakan bahwa sejak 1870 hingga 1990, jumlah bank sentral bertambah menjadi 180 buah.18 Tetapi yang terpenting kita lihat adalah bahwa proses kinerja "uang" yang bermuara kepadalahirnya bank sentral di berbagai negara-bangsa tak pernah luput dari keterbenturannya dengan aspek-aspek sosial-ekonomi dan politik, sesuatu yang secara teknikal tak berhubungan dengannya.

\section{Politik-Ekonomi Bank Indonesia}

Pada hemat saya, hanya dalam konteks inilah kita lebih bisa memahami secara lebih komprehensif lingkungan politik-ekonomi Bank Indonesia sebagai bank sentral negeri "Nyiur Melambai" ini. Bank sentral Indonesia memang bukan produk Revolusi Nasional 1945-1949, seperti halnya Bank Negara Indonesia (BNI). Akan tetapi tidak bisa dinafikkan bahwa kelahiran- nya pada 1952 adalah sebuah produk politik — karena perasaan nasionalisme masyarakat baru merdeka meningkat dan mendorong terjadinya nasionali- sasi De Javasche Bank milik Belanda.19 Karena itu, kendati harus bekerja secara teknikal, kehadiran Bank Indonesia mempunyai misi sosial-politik.

Beberapa di antara misi sosial-politik itu terletak pada budaya "uang" dan struktur kapital masyarakat Indonesia. Dari segi budaya, tidak bisa disang- kal bahwa masyarakat Indonesia yang baru merdeka pada esensinya masih sangat terbelakang. Jika dibandingkan dengan pengalaman masyarakat Belanda yang pada abad KE-17, seperti telah kita lihat di atas, telah mengem- bangkan sistem inovatif dalam sektor finansial, yaitu joint stock, hingga pertengahan abad KE-20, yakni 3 abad kemudian, masyarakat Indonesia masih mengalami financial shallowing (rendahnya budaya menggunakan uang sebagai aktivitas ekonomi)20 Berbagai studi memang memperlihatkan betapa terbelakangnya masyarakat Indonesia dalam memperlakukan "uang". Munculnya berbagai mitos tentang "uang", bahkan hingga hari ini, untuk sebagian mendukung dugaan di atas.

Sebagian lainnya adalah karena kebanggaan akan identitas Indonesia yang baru merdeka. Bagaimanapun juga harus kita akui, sejarah "uang" di Nusan- tara ini tidak berjalan lurus. Selain jenis-jenis "uang" tradisional, sistem moneter kita didominasi dalam waktu yang cukup lama oleh alat pemba- yaran kolonial Belanda. Sejak 1942, "uang" yang berlaku di tengah masya- rakat adalah yang diciptakan Jepang. Maka tak mengherankan, ketika ORI (Oeang Repoeblik Indonesia) dicetak pada 1945, setelah Jepang menyerah kepada Tentara Sekutu, tidak secara otomatis diterima di tengah-tengah masyarakat.21 Dalam 
Konfrontasi: Jurnal Kultur, Ekonomi dan Perubahan Sosial, 3 (2) Juli 2016, 1-8

P-ISSN: 1410-881X (Print)

Fachry Ali, Bank Sentral dan Lingkungan Politik Ekonomi: Pengalaman Indonesia

DOI: -

http://www.konfrontasi.net/index.php/konfrontasi2

spekulasi saya, terutama karena Belanda kembali men- duduki hampir sebagian besar wilayah Indonesia pada 1945-49, "uang" kolonial Hindia Belanda kembali dipergunakan.

Dalam situasi inilah keabsahan atau legitimasi kemerdekaan Indonesia di hadapan rakyat ditentukan oleh apakah "uang" yang dicetak secara resmi digunakan oleh penduduk Indonesia atau tidak. Hal inilah yang disuarakan Gubernur Bank Indonesia pertama Sjafruddin Prawiranegara:

"It was exactly among the "underdeveloped" and primitive society like Indonesians that thrust in the country's currency became a barometer of people's confidence in the government and a measuring stick of govern- ment's authority on the people. The lesser the people trust in the official currency the lesser the government's authority on the people, and the lesser the possibility of the goverment to carry out its duty as normal.22

Dengan melihat ini, menjadi jelas bagi kita bahwa bank sentral di Indonesia tidak berdiri terasing dari masalah-masalah sosial-politik. Bahkan di dalam beberapa hal, jika ucapan Sjafruddin Prawiranegara diatas ditelitidengan seksama, peranan politik bank sentralmenjadisesuatu yang crucial. Semen- tara dari segi kekuatan politik, militer dan profesionalisme negara dan bangsa Indonesia yang baru merdeka masih harus diuji, "uang" hasil cetak- annya diterima secara penuh oleh masyarakat. Hal ini mengindikasikan — seperti tersirat dalam ucapan Sjaruddin di atas - penerimaan dan penga- kuan politik dari rakyat atas kehadiran Indonesia sebagai sebuah negara yang merdeka.

Ringkasnya, keberadaan bank sentral secara struktural akan selalu terkait dengan politik, secara langsung atau tidak. Namun demikian, terutama karena bukan lembaga politik, maka bank sentral tidak mungkin bertindak sebagai inisiator dalam kebijakan-kebijakan non-moneter. Melainkan, seba- gai pihak yang dipengaruhi. Dalam arti kata lain, di dalam konteks politik, bank sentral bukanlah subyek, melainkan obyek yang secara terus-menerus berpotensi mengalami proses subordinasi. Contoh paling fatal dan ironis dari proses subordinasi ini adalah ketika pada 1960-AN Bank Indonesia, sebagai bank sentral, dilebur menjadi bagian dari BNI. Ini dengan jelas dapat kita lihat dari deskripsi Widigdo Sukarman:

"Pada 1964, atas dasar pertimbangan politik untuk mempermudah ko- mando di bidang perbankan, pemerintah menetapkan kebijakan mengin- tegrasikan seluruh bank-bank pemerintah ke dalam suatu bank dengan nama Bank Negara Indonesia. Prakarsa pengintegrasian bank pemerin- tah ini diusulkan oleh Jusuf Muda Dalam, Menteri Bank Sentral/Guber- nur Bank Indonesia dan disetujui oleh Presiden Soekarno. Ide dasarnya adalah menjadikan perbankan sebagai "alat revolusi" dengan motto "Bank Berjuang" di bawah pimpinan "Pemimpin Besar Revolusi".

Kasus ini bukan saja mengindikasikan ketakberdayaan bank sentral atas tekanan politik, melainkan juga memperlihatkan kecenderungan struktural otoritas politik untuk mengontrolnya. Dan kontrol yang semacam ini tidak berhenti ketika rezim berganti. Di bawah Orde Baru (1996-1998), bank sentral tetap berada di bawah pengaruh politik pembangunan. Di sini, harus diakui bahwa pengaruh politik tersebut lebih bersifat "teknokratis", dalam arti subordinasi bank sentral ditujukan untuk menciptakan efek pemba- ngunan ekonomi yang relatif terukur.

Namun demikian, seperti disayangkan Anwar Nasution, kebijakan semacam ini telah memperkecil ruang manuver bank sentral untuk bertindak sebagai penjaga stabilitas moneter sebagai- mana memang telah menjadi tugas pokok bank sentral di manapun.24Dalam arti kata lain, apa yang dimaksud- kan manuver tersebut mengandung gagasan kebutuhan independensi sebu- ah bank sentral. 
Konfrontasi: Jurnal Kultur, Ekonomi dan Perubahan Sosial, 3 (2) Juli 2016, 1-8

P-ISSN: 1410-881X (Print)

Fachry Ali, Bank Sentral dan Lingkungan Politik Ekonomi: Pengalaman Indonesia

DOI: -

http://www.konfrontasi.net/index.php/konfrontasi2

Hanya di masa Presiden BJ Habibie (1998-1999), cita-cita yang bersifat teknokratik ini terealisir.25 Akan tetapi, harus cepat-cepat kita nyatakan di sini bahwa independensi tersebut lebih merupakan sebuah kreasi politik. Dalam arti bahwa keruntuhan rezim Orde Baru telah memungkinkan penguasa politik yang menggantikannya mengubah langgam cengkraman politik atas bank sentral. Sepanjang otoritas politik berpegang teguh kepada gagasan tersebut, sepanjang itu pula independensi bank sentral bisa diper- tahankan. Pernyataan ini dengan sangat jelas terbukti di masa kepresiden- an Abdurrahman Wahid (1999-2001). Jauh dari kesadaran tentang strategis- nya mempertahankan independensi bank sentral, Presiden Abdurrahman Wahid telah berusaha melangkahi seluruh bangunan Undangundang Bank Indonesia dengan menggunakan otoritas politik yang dimilikinya untuk melakukan intervensi ke dalam susunan anggota gubernur bank sentral.

Dengan menyatakan ini, saya ingin menyampaikan pendapat bahwa secara struktural bank sentral di Indonesia akan selalu terkait atau terbawa ke dalam arus besar pergolakan politik. Reformasi politik yang berlangsung sejak 1998 hingga kini, secara teoritis, adalah sebuah proses konsolidasi sistem demokrasi. Tetapi secara substansial adalah pemencaran kekuasaan secara tidak sistematis dari istana ke wilayah-wilayah yang kian menjauh dari "pusat kekuasaan" - yang secara konvensional kita pahami. Implikasi paling nyata dari pemencaran kekuasaan ini adalah rekrutmen calon-calon pemegang otoritas politik tidak lagi melalui kontestasi lama: "kepiawaian teknokratis". Melainkan, melalui kontestasi publik. Ini berarti bahwa proses seleksi tersebut berlangsung dalam struktur yang longgar, karena mereka yang tampil ke atas panggung kekuasaan lebih didasarkan pada kemampuan membujuk massa. Dan massa yang pada umumnya tidak berhasrat kepada gagasan-gagasan yang bersifat teknokratik, cenderung memilih mereka yang dianggap populer.

Proses seleksi pemimpin politik yang semacam inilah yang menyebabkan bank sentral mengalami "alienasi". Sifat kinerjanya yang sepenuhnya bertumpu pada segi-segi teknikalmoneter bukan saja "membosankan" dilihat dari konteks massa, melainkan juga terlalu rumit untuk dicerna. Akibatnya adalah bank sentral hanya mampu mengkomunikasikan diri kepada kha- layak terbatas: kaum profesional dan para pengusaha yang merasakan lang- sung pengaruh kebijakan-kebijakan yang dibuat oleh bank sentral. Sementara para politisi, yang kini mempunyai otoritas politik, tenggelam dalam kalkulasi kekuasaan bersiklus lima tahunan, dan karena itu tidak sempat membuat perenungan jangka panjang. Padahal kita tahu, habitat yang sehat bagi bank sentral yang independen terletak pada keterjaminannya berkinerja dalam jangka panjang.

\section{Bibliografi}

A. Brealy, Richard, et-al, Financial Stability and Central Banks (London and New York: Routledge, 2001).

Ali, Fachry, Effendy, Bahtiar, Juoro, Umar dan Dahlan, Musfihin, The Politics of Central Bank: The Position of Bank Indonesia Governor in Defending Independence (Jakarta: LSPEU Indonesia, 2003).

Bagehot, Walter, Lombard Street: A Description of the Money Market (New York, et-al: John Wiley and Sons, Inc., 1999).

Beng To, Oey, Sejarah Kebijakan Moneter Indonesia, Jilid I (1945-1958) (Jakarta: Lembaga Pengembangan Perbankan Indonesia, 1991). 
Konfrontasi: Jurnal Kultur, Ekonomi dan Perubahan Sosial, 3 (2) Juli 2016, 1-8

P-ISSN: 1410-881X (Print)

Fachry Ali, Bank Sentral dan Lingkungan Politik Ekonomi: Pengalaman Indonesia

DOI: -

http://www.konfrontasi.net/index.php/konfrontasi2

Braudel, Fernand, The Structure of Everyday Life: The Limits of the Possible, terjemahan dari bahasa Perancis ke dalam bahasa Inggris oleh Sian Reynold (Berkeley, Los Angeles: University of California Press, 1992).

Brewer, John, The Sinews of Power: War, Money and the English State, 1688-1788 (New York: Alfred A. Konf, 1989).

Ferguson, Niall, Empire: How Britain Made The Modern World (London: Penguin BookS,2003).

Ferguson, Niall, The Ascent of Money: A Financial History of the World

(London: Penguin Books).

L. Heilbroner, Robert, The Making of Economic Society (Englewood Cliff, NJ: PrenticeHall, InC., 1962).

Marshall, Alfred, Money, Credit, and Commerce (New York: Promotheus Books, 2003).

Maxfied, Sylvia, Gatekeeper of Growth: The International Political Eco- nomy of Central Banking in Developing Countries (Princeton, New Jersey: Princeton University Press, 1997).

Nasution, Anwar, Financial Institutions and Policies in Indonesia

(Singapore: ISEAS, 1983).

Rahardjo, M. Dawam, et.al, Bank Indonesia dalam Lintasan Sejarah (Jakar- ta: LP3ES, 1996)

S. Mishkin, Frederick, The Economics of Money, Banking and Financial Markets (Massachussetts: Addison-Wesley, 1997), Fifth Edition.

Sukarman, Widigdo, "Liberalisasi: Telaah Politik-Ekonomi Perbankan Masa Orde Baru", disertasi doktor, Program Studi Ilmu-ilmu Sosial dan Politik, Jurusan Ilmu-ilmu Sosial, Program Pasca Sarjana, Universitas Gajah Mada, Yogyakarta, 2003. 